\title{
GP9 Gene
}

National Cancer Institute

\section{Source}

National Cancer Institute. GP9 Gene. NCI Thesaurus. Code C126552.

This gene plays a role in von Willebrand factor binding. 